\title{
Allelopathic potential of the dinoflagellate Alexandrium tamarense on marine microbial communities
}

\author{
Astrid Weissbach ${ }^{\mathrm{a}, *}$, Urban Tillmann ${ }^{\mathrm{b}}$, Catherine Legrand ${ }^{\mathrm{a}, \mathrm{b}}$ \\ ${ }^{a}$ Marine Ecology section, School of Natural Sciences, Linnæus University, SE-39182 Kalmar, Sweden \\ b Alfred Wegener Institute for Polar and Marine Research, Am Handelshafen 12, D-27570 Bremerhaven, Germany
}

\section{A R T I C L E I N F O}

\section{Article history:}

Received 31 December 2009

Received in revised form 27 April 2010

Accepted 26 May 2010

\section{Keywords:}

Alexandrium spp.

Allelopathy

Algae

Bacteria

North Sea

PSP

\begin{abstract}
A B S T R A C T
The impacts of two strains of the dinoflagellate Alexandrium tamarense, differing in lytic activity, on the abundance and the composition of microbial communities $(<150 \mu \mathrm{m})$ were studied in North Sea water during spring with Phaeocystis globosa as a dominant species. Cell-free suspensions (supernatant) of exponentially growing lytic and non-lytic Alexandrium culture were added at different concentrations to natural microbial communities under nutrient rich conditions. The non-lytic strain had a positive impact on diatoms whereas the lytic strain suppressed phytoplankton growth in comparison to the control. $P$. globosa, present as single cells in the initial community, increased in abundance and formed colonies in all treatments. However, total abundance and number of colonies was low with lytic Alexandrium additions, whereas shape of the colonies, but not abundance of cells, was affected by non-lytic Alexandrium additions. During the 4-day experiment, bacterial abundance was constantly higher with high lytic additions (highest concentration equivalent to 1000 cells ml$^{-1}$ ) whereas nanoflagellate abundance in the same treatments was found to be lower at the end of the experiment. Initial bacterial community composition differed significantly among lytic Alexandrium, non-lytic Alexandrium and North Sea water. However, neither bacterial activity nor composition was significantly affected by the supernatants after $96 \mathrm{~h}$. Our results indicated that Alexandrium allelochemicals do not inhibit growth and production of bacteria in seawater collected during spring in the North Sea.
\end{abstract}

(c) 2010 Elsevier B.V. All rights reserved.

\section{Introduction}

The adverse effects of harmful algal blooms (HABs) in marine ecosystems have focused attention on defining the role of factors that determine their abundance and distribution. Some marine dinoflagellates of the genus Alexandrium Halim (Balech) produce neurotoxins, which cause Paralytic Shellfish Poisoning (PSP), resulting in life-threatening human illness due to the consumption of contaminated seafood (Anderson, 1997). Blooms of toxic Alexandrium spp. occur worldwide, usually associated with embayments, estuaries or open coastal waters. Alexandrium spp. neurotoxins can also be transferred through the marine food web to higher trophic levels where they may affect zooplankton, fish, birds and marine mammals. Alexandrium species also release lytic compounds suppressing competitors (Fistarol et al., 2004; Tillmann et al., 2007) and heterotrophic micrograzers (Tillmann and John, 2002). Allelopathy is a known phenomenon in a number of phytoplankton groups (e.g. Cyanobacteria, Haptophytes, Dinoflagellates) and has been hypothesized to be one of the forces structuring phytoplankton communities (Legrand et al., 2003) and

\footnotetext{
* Corresponding author.

E-mail address: astrid.weissbach@lnu.se (A. Weissbach).
}

the formation of harmful algal blooms (Smayda, 1997). Chemical interactions among $A$. tamarense and other marine protists are an important biological factor for the dominance of Alexandrium, not solely restricted to the competition for nutrients (Fistarol et al., 2004; Tillmann et al., 2008). Although bacteria and phytoplankton are closely linked in coastal systems, little is known about their interactions in shaping the pelagic microbial communities (Riemann et al., 2000; Hay and Kubanek, 2002; Mayali and Azam, 2004). A few studies have shown that bioactive compounds produced by phytoplankton can inhibit bacteria (Ribalet et al., 2008; Doucette, 1995). However, experiments with natural communities showed higher bacterial abundances in presence of allelochemicals (Fistarol et al., 2004; Uronen et al., 2007). The flagellate Prymnesium parvum produces compounds that can lyse competitor cells and alter the functioning of the planktonic food web by increasing carbon transfer through the microbial loop (Uronen et al., 2007). Hence, phytoplankton may select for a specific phylogenetic and/or phenotypic composition of microbial communities in its surrounding environment. Many studies report the phylogenetic composition of bacterioplankton during Alexandrium blooms (Green et al., 2004; Wichels et al., 2004; Jasti et al., 2005; Sala et al., 2005). However, the mechanisms creating a specific type of phytoplankton-bacteria assemblage are unknown. The aim of this study was to examine the allelopathic effect of the 
dinoflagellate Alexandrium on bacterial and natural plankton communities using field samples from the North Sea and cultures of $A$. tamarense. Here, we compare the response of a plankton community to extracellular compounds produced by two strains of A. tamarense (lytic and non-lytic). This comparative approach was chosen to distinguish between the impact of the added $A$. tamarense suspension per se and the impact of lytic compounds, produced by $A$. tamarense, which can not be separated from other algal exudates today.

\section{Materials and methods}

\subsection{Algal cultures}

Alexandrium tamarense strains (Alex2 and Alex5) were isolated from the east coast of Scotland (North Sea) in 2004 (Alpermann et al., 2009) and grown non-axenic in K-medium (Keller et al., 1987). These two clones were selected based on lytic capacity quantified by a Rhodomonas bioassay (Tillmann et al., 2009). Alex5 was found to have no lytic impact on Rhodomonas and will further be referred to as non-lytic Alexandrium. Alex2 had a high lytic capacity and is therefore called lytic Alexandrium in the further text.

Both A. tamarense and Rhodomonas salina (Kalmar Algal Collection, KAC 30) were grown in batch cultures in K-medium (salinity 32), prepared from sterile-filtered (VacuCap $0.2 \mu \mathrm{m}$ Pall Life Sciences) North Sea water in $2000 \mathrm{ml}$ Erlenmeyer flasks. Cultures were maintained under controlled conditions at $15^{\circ} \mathrm{C}$ under cool-white fluorescent light $\left(65 \mu \mathrm{mol} \mathrm{m} \mathrm{m}^{-2} \mathrm{~s}^{-1}\right)$ on a $16 \mathrm{~h}$ light:8 h dark cycle. Prior to sampling, culture flasks were shaken gently by hand to allow for a homogenous cell distribution.

To quantify the lytic activity of $A$. tamarense on natural plankton communities, cell-free supernatant of $A$. tamarense cultures was used since filtration can remove up to $90 \%$ of the allelopathic activity probably due to absorption of the bioactive compounds on the filter (Tillmann et al., 2008). Aliquots $(18 \times 50 \mathrm{ml})$ of exponentially growing cultures of $A$. tamarense (lytic and nonlytic Alexandrium, 5000 cells $\mathrm{ml}^{-1}$ ) were centrifuged for $15 \mathrm{~min}$ at $12,000 \mathrm{rpm}$. Aliquots of supernatant $(30 \mathrm{ml})$ were stored in a glass bottle at $4{ }^{\circ} \mathrm{C}$ in the dark and used within 5 days. The lytic activity of the supernatant was checked prior the experiment using a Rhodomonas bioassay (bioassay modified after Tillmann et al., 2009). Additionally, bacterial abundance and community composition in lytic and non-lytic Alexandrium supernatant and the North Sea water were measured.

\subsection{Field sampling}

A natural plankton community was collected during spring in May 2007 in the southern Helgoland Bight (North Sea) from the surface sampled with a bucket. Seawater was filtered through $150 \mu \mathrm{m}$ nylon nets to remove zooplankton and large detritus. Samples for bacterial abundance (in triplicates, $1.5 \mathrm{ml}$ each) and production, chl a concentration (in triplicates, $300 \mathrm{ml}$ each), phytoplankton $(50 \mathrm{ml})$ and bacterial community composition $(500 \mathrm{ml})$ were immediately taken. Nitrate $(580 \mu \mathrm{M}$ final concentration), phosphate ( $36 \mu \mathrm{M}$ final concentration) and peptone ( $2 \mathrm{mg} \mathrm{Cl}^{-1}$ ) were added to ensure nutrient saturated conditions for both, phytoplankton and bacteria. Enriched seawater (400$495 \mathrm{ml}$ ) was placed in 11 glass bottles and incubated at $15^{\circ} \mathrm{C}$ overnight prior to the experiment start.

\subsection{Allelopathic effect of Alexandrium supernatant on microbial communities}

Lytic and non-lytic Alexandrium supernatant were added, respectively, in three treatments (each in triplicates) corresponding to the lytic activity of 200 (low continuous addition), 1000 (high continuous addition) and 1000 (single addition) cells $\mathrm{ml}^{-1}$, respectively.

The single addition corresponding to 1000 cells ml $^{-1}$ was added in $100 \mathrm{ml}$ supernatant at $T_{0}$ to a final volume of $500 \mathrm{ml}$. Continuous additions corresponding to 300 (high continuous addition) and 50 (low continuous addition) cells $\mathrm{ml}^{-1}$ were added daily in 30 and $5 \mathrm{ml}$ of supernatant $\left(T_{0}, T_{24}, T_{48}, T_{72}\right)$ to a final volume of 515 and $590 \mathrm{ml}$, respectively. We added Kmedium to the control to obtain comparable nutrient conditions in control as well as Alexandrium treatments. Due to the different amounts of added supernatant, overall nutrient concentrations between treatments and controls may have slightly differed. However, since A. tamarense was cultivated in full K-medium, and the supernatant was produced during exponential growth, we assume that the amount of nutrients added to both the Alexandrium treatments as well as the controls exceeded the amount of nutrient that could possibly be used by phytoplankton and bacteria during the $96 \mathrm{~h}$ of incubation. $30 \mathrm{ml}$ of K-medium were added daily $\left(T_{0}, T_{24}, T_{48}, T_{72}\right)$ to triplicate control bottles to a final volume of $590 \mathrm{ml}$. All bottles were incubated for $96 \mathrm{~h}$ under similar conditions as the algal cultures. Samples for bacterial abundance were taken daily. After $96 \mathrm{~h}$ (Day 4), samples for bacterial abundance and production, chl a, phytoplankton and bacterial community composition were collected in treatments and controls. From $T_{24}$ and $T_{96}$, bacterial volumes in the treatments were calculated. Samples for bacteria counts were fixed in $2 \%$ formalin and placed at $4{ }^{\circ} \mathrm{C}$. Whole water samples $(20 \mathrm{ml})$ were filtered on glass fiber filters (Gelman A/E) and frozen at $-20^{\circ} \mathrm{C}$ prior to chl a analysis. Samples for identification and quantification of phytoplankton were preserved with Lugol's solution. For extraction of bacterial community DNA, microbial biomass from 50 to $400 \mathrm{ml}$ seawater was collected onto $0.2 \mu \mathrm{m}$-pore-size Supor 200 membrane filters by vacuum filtration at $<150 \mathrm{mmHg}$. Filters were stored frozen at $-20^{\circ} \mathrm{C}$ in TE buffer $(10 \mathrm{mM}$ Tris, 1 mM EDTA).

\subsection{Analytical procedures}

\subsubsection{Rhodomonas bioassay}

A dilution series was made using different amounts of Alexandrium supernatant and whole cell culture corresponding to the following Alexandrium cell densities: 50, 75, 100, 150, 250, $375,635,937,1250,2500$ cells $\mathrm{ml}^{-1}$ in a total bioassay volume of $4 \mathrm{ml}$. K-medium (triplicate) served as control. $R$. salina was spiked to all samples to a final density of $12,500 R$. salina cells $\mathrm{ml}^{-1}$. After an incubation period of $3 \mathrm{~h}$, samples were fixed with Lugol's solution ( $2 \%$ final concentration) and counted with an inverted microscope (Zeiss Axiovert 35). A sub-area corresponding to at least 500 cells in the control was counted. Values of $\mathrm{EC}_{50}$, defined as the Alexandrium cell concentration causing lysis of $50 \%$ of target cells, were calculated by using a sigmoidal curve fit function (Tillmann et al., 2009) in the mathematical programme Origin.

\subsubsection{Chlorophyll a and enumeration of phytoplankton and nanoflagellates}

Chlorophyll a concentration was measured fluorometrically (Turner AU-10 fluorometer) after $8 \mathrm{~h}$ extraction in the dark with 96\% ethanol (Jespersen and Christoffersen, 1987). For each treatment, phytoplankton growth day ${ }^{-1}$ was calculated by using the following Eq. (1):

$$
\mu=\left(L N\left(\mathrm{Chl}_{96}\right)-L N\left(\mathrm{Chl}_{0}\right)\right) \frac{1}{4}
$$


Except Phaeocystis globosa, phytoplankton was counted using a Zeiss Axiovert inverted microscope and, when possible, identified at the species or genus level. The volume sedimented for the counts $(5-50 \mathrm{ml})$ varied between different treatments. The total number of intact cells counted was always $>200$ per sample, except for the highest lytic Alexandrium treatments with $>100$ total counts per sample. P. globosa colonies were observed and counted in fresh samples fixed with Lugol's solution a few hours after sampling. P. globosa total cells and nanoflagellates were counted at $1000 \times$ using an Olympus BX50 inverted microscope and blue light epifluorescence. Samples fixed with Lugol's solution were bleached with sodium iodide and stained for 2 min with proflavine (Haas, 1982). Stained samples were filtered onto $0.8 \mu \mathrm{m}$ black polycarbonate filters. At least $300 \mathrm{P}$. globosa cells per filter were counted, except in the initial community and lytic Alexandrium single addition treatments, where approximately $100 \mathrm{P}$. globosa cells per filter were counted. Nanoflagellates $<10 \mu \mathrm{m}$ and $>10 \mu \mathrm{m}$ were counted in the same way to estimate bacterial grazing pressure. At least 250 nanoflagellates per filter were counted, except in the initial community where 100 nanoflagellates per filter were counted.

\subsubsection{Bacterial abundance and production}

Heterotrophic bacteria were counted using flow cytometry (BD FACs Calibur) after staining with Syto13 DNA dye (Gasol and Del Giorgio, 2000). Bacterial production was measured as carbon production by the uptake of ${ }^{3} \mathrm{H}$-leucine (Smith and Azam, 1992). For each sample, triplicate aliquots $(1.2 \mathrm{ml})$ and a trichloroacetic acid killed control were incubated with $40 \mathrm{nM}\left[{ }^{3} \mathrm{H}\right]$ Leucine (final concentration) for $1-2 \mathrm{~h}$ at $15^{\circ} \mathrm{C}$. For the natural community and the Alexandrium supernatant, four aliquots and two controls were incubated with $40 \mathrm{nM}\left[{ }^{3} \mathrm{H}\right]$ Leucine to measure bacterial production. $\left[{ }^{3} \mathrm{H}\right]$ Leucine concentration was measured in dpm by using a scintillation counter and converted to bacterial carbon production ( $\mu \mathrm{g} \mathrm{Cl}^{-1} \mathrm{~h}^{-1}$ ) using the conversion factor of 0.86 (Simon and Azam, 1989).

\subsubsection{Bacterial biomass}

To calculate bacterial biomass, at least 100 bacteria in treatments containing K-medium and single (1000 cells ml ${ }^{-1}$ ) and high continuous ( 1000 cells $\mathrm{ml}^{-1}$ ) additions of lytic and nonlytic Alexandrium supernatant were measured using epifluorescence microscopy photographs (1000 magnification) and Gimp Software. The volume of bacteria with the largest side smaller than $0.5 \mu \mathrm{m}$ was calculated as a sphere, whereas all bacteria with the largest side larger than $0.5 \mu \mathrm{m}$ were calculated as a cylinder with an average thickness of $0.36 \mu \mathrm{m}$. Bacterial volume was converted into bacterial carbon biomass by using the conversion factor of

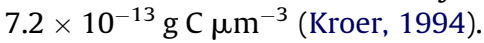

\subsubsection{DNA extraction, PCR amplification and denaturing gradient gel electrophoresis (DGGE)}

DNA was extracted directly from filters as previously described (Boström et al., 2004). Briefly, cells were treated with lysozyme, proteinase $\mathrm{K}$ and sodium dodecyl sulphate followed by phenolchloroform-isoamyl alcohol extraction. The 16S rRNA gene fragment (approximately $550 \mathrm{bp}$ long) was amplified by PCR, using the bacteria specific primer GM5 GC (corresponding to placers 341-358 of the Escherichia coli 16S rRNA) and the universal primer $907 \mathrm{RM}$ (corresponding to positions 907-927 of the $E$. coli $16 \mathrm{~S}$ rRNA). The reaction mixture volumes were $100 \mu \mathrm{l}$, containing $10-50 \mathrm{ng}$ DNA template, $200 \mu \mathrm{M}$ of both primers, $48 \mu \mathrm{l}$ PCR water and $50 \mu \mathrm{l}$ Master mix (including $5 \mathrm{U} / \mathrm{ml}$ Taq DNA polymerase, $400 \mu \mathrm{M}$ dNTP's, $3 \mu \mathrm{M} \mathrm{MgCl}_{2}$ ). The template DNA was denatured in a thermal cycler for 5 min at $95{ }^{\circ} \mathrm{C}$ followed by a touchdown PCR as described by Muyzer and Smalla (1998), to increase the specificity of amplification. PCR products were visualized by agarose gel electrophoresis with a molecular size standard in the gel. Approximately $80 \mu \mathrm{l}$ of the template was mixed with $20 \mu l 6^{*}$ loading buffer and the gel was loaded on a $6 \%$ polyacrylamide gel with a denaturing gradient that ranged from 20 to $80 \%$ (where $100 \%$ is defined as $7 \mathrm{M}$ urea and $40 \%$ deionized formamide). The gel was run at $200 \mathrm{~V}$ for $3.5 \mathrm{~h}$ in 1 TAE running buffer (40 mM Tris ( $\mathrm{pH} 7.4$ ), $20 \mathrm{mM}$ sodium acetate, 1 mM EDTA). The gel was stained with ethidium bromide for $30 \mathrm{~min}$ and visualized by UV luminescence.

\subsection{6. $P C R$ and transverse restriction fragment length polymorphism (TRFLP)}

The genetic fingerprinting technique terminal restriction fragment length polymorphism is based on the restriction digestion of fluorescently labelled PCR products. A 16S rRNA gene fragment (approximately 550 bp long) was amplified by $\mathrm{PCR}$, using the bacteria specific primer $21 \mathrm{~F}$ and the universal primer $907 \mathrm{RM}$. The reaction mixture volumes were $50 \mu \mathrm{l}$, containing $10-50 \mathrm{ng}$ DNA template, $100 \mu \mathrm{M}$ of both primers, $22 \mu \mathrm{l}$ PCR water and $25 \mu \mathrm{l}$ Master mix (including 5U/ml Taq DNA polymerase, $400 \mu \mathrm{M}$ dNTP's, $3 \mu \mathrm{M} \mathrm{MgCl}_{2}$ ).). The template DNA was denatured in a thermal cycler for $5 \mathrm{~min}$ at $95{ }^{\circ} \mathrm{C}$ followed by PCR. PCR products were visualized by agarose gel electrophoresis with a molecular size standard in the gel. The PCR product was cleaned by using Sephadex and digested with the restriction enzyme Alu 1. After an additional cleaning, the digested product was marked with the Map Marker 1000 and denatured. The following step, the capillary electrophoresis, separated the labelled fragments after their length. The data was visualised and analysed by using the applied biosystems software Gene mapper (applied biosystems). A statistical analysis in Past (Hammer et al., 2001) was performed to compare the different treatments.

\subsubsection{Statistics}

Statistic tests were accomplished using Statistica software (Stat Soft Inc.). To test for significant differences between control and treatments or between $A$. tamarense non-lytic and lytic supernatant additions of the same concentration, independent samples $t$-tests ( 2 different groups) were used. Since data from control treatments were repeatedly analysed, the level of significance was reduced to 0.008 (Bonferroni adjustment) instead of 0.05 for $t$-tests comparing controls to various treatments. To test for significant differences between all groups, One Way ANOVA was used. Data was tested for normal distribution (Kolmogorov-Smirnov test) ( $t$-test, One Way ANOVA) and homogeneity of variances (Cochran's test) (One Way ANOVA). If the assumptions for parametric tests could not be fulfilled, data were LOG or SQRT transformed. Differences between treatments were significant at $p<0.05$.

\subsubsection{Analysis of DGGE gels}

DGGE gel band patterns were subjected to computer analysis to compare the bacterial community structure using the program Quantity One (Bio Rad). On basis of the volume and band pattern in the gel, a dendrogram (Algorithm: UPGMA) of the samples was prepared.

\subsubsection{Analysis of TRFLP patterns}

For the TRFLP analysis, non-metric multi dimensional scaling analysis was conducted to assess for the relationship between the different treatments. Non-metric multi dimensional scaling was performed with PAST software package (Hammer et al., 2001). 


\section{Results}

\subsection{Characterisation of A. tamarense cell-free supernatants}

Lytic Alexandrium caused cell lysis of $R$. salina in a dosedependent manner with an $\mathrm{EC}_{50}$ of $110 \pm 50$ A. tamarense cells $\mathrm{ml}^{-1}$. Cell-free supernatant was slightly less effective $\left(\mathrm{EC}_{50}=180 \pm 4 \mathrm{~A}\right.$. tamarense cells $\left.\mathrm{ml}^{-1}\right)$. Non-lytic Alexandrium supernatant or culture did not lyse $R$. salina at any concentration. Bacterial abundance was 4 times higher in lytic Alexandrium cultures

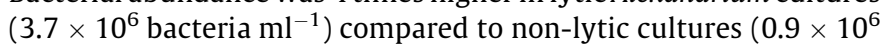
bacteria $\left.\mathrm{ml}^{-1}\right)$. However, bacteria were on average twice as large in non-lytic Alexandrium culture $\left(0.15 \mu \mathrm{m}^{3}\right)$ compared to the lytic culture $\left(0.07 \mu \mathrm{m}^{3}\right)$ because the non-lytic culture contained large filamentous bacteria that were not observed in the lytic Alexandrium culture. Thus, bacterial biomass in the lytic Alexandrium culture $\left(188 \mu \mathrm{g} \mathrm{C}^{-1}\right)$ was twice as high as in the non-lytic Alexandrium culture $\left(95 \mu \mathrm{g} \mathrm{C}^{-1}\right)$. Bacterial production was significantly higher in lytic Alexandrium compared to non-lytic Alexandrium culture $\left(228 \pm 32 \mathrm{~d}^{-1}\right.$ and $183 \pm 12 \mathrm{~d}^{-1}$, respectively). However, production biomass $^{-1}$ was lower in lytic Alexandrium compared to non-lytic Alexandrium culture $\left(1.2 \pm 0.2 \mathrm{~d}^{-1}\right.$ and $1.9 \pm 0.1 \mathrm{~d}^{-1}$, respectively). Centrifugation resulted in $90 \%$ (lytic Alexandrium) and $85 \%$ (non-lytic Alexandrium) reduction in bacterial numbers in the supernatant. Bacterial production in lytic and non-lytic Alexandrium supernatant was approximately $75 \%$ lower as in the corresponding cultures. Production biomass ${ }^{-1}$ was higher in Alexandrium supernatant compared to the Alexandrium cultures and equal in lytic and nonlytic Alexandrium supernatant.

\subsection{Effect of A. tamarense on North Sea phytoplankton and nanoflagellates}

Seawater was collected during the spring at a moderate chl a concentration of $3.7 \mu \mathrm{g} \mathrm{Chl} \mathrm{a}{ }^{-1}$. In 2007, the spring phytoplankton was dominated by the colony forming P. globosa (Haptophyte) and cryptophytes (Table 1 ).

Table 1

Plankton composition of the initial North Sea water.

\begin{tabular}{llr}
\hline Group & Genus/species & ${\text { Cells }{ }^{-1}}^{-1}$ \\
\hline Dinoflagellates & Gyrodinium spirale & 7079 \\
& Scrippsiella spp. & 6262 \\
& Protoperidinium spp. & 4901 \\
& Dinophysis acuminata & 4084 \\
& Pyrophacus horrologium & 2178 \\
& Prorocentrum micans & 545 \\
& Alexandrium spp. & 240 \\
& Polykrikos schwartzii/kofoidii & 140 \\
& Ceratium lineatum & 40 \\
Cryptophytes & Teleaulax spp. & 43224 \\
& Leucocryptos spp. & 6372 \\
Haptophytes & Phaeocystis globosa & 971307 \\
Diatoms & Pseudonitzschia spp. & 7351 \\
& Leptocylindrus danicus & 2723 \\
Chaetoceros spp. & 1260 \\
Unidentified & Rhizosolenia spp. & 420 \\
nanoflagellates $>10 \mu \mathrm{m}$ & Ditylum brightwellii & 320 \\
& Guinardia delicatula & 50 \\
& Coscinodiscus spp. & 40 \\
& Laboea strobila & 2040 \\
& &
\end{tabular}

Phytoplankton biomass, measured as chl a, increased during the experiment in all treatments at very different rates. The growth rate of the phytoplankton community, calculated from chl a measured initially and at the end of the experiment, was significantly lower in high lytic Alexandrium additions ( $t$-test, $p<0.008 ; \mu=0.32 \mathrm{~d}^{-1}$ (single addition) and $\mu=0.48 \mathrm{~d}^{-1}$ (high continuous addition)) compared to control treatments $\left(\mu=0.72 \mathrm{~d}^{-1}\right)$. All other treatments did not differ significantly from the control ( $t$-test, $p>0.008$ ).

The plankton community composition changed over the course of the experiment; cryptophytes disappeared and both diatoms and P. globosa became dominant in all treatments (Fig. 1 and Table 1).

Below, plankton community composition of the different treatments will be compared to the control treatments. Low continuous additions of Alexandrium supernatant did not affect phytoplankton and nanoflagellate groups. High continuous additions of lytic supernatant inhibited the abundance of $P$. globosa and large flagellates compared to the control. Chaetoceros spp. benefitted from high continuous additions of non-lytic Alexandrium supernatant. In single additions of lytic Alexandrium supernatant, $P$. globosa and Chaetoceros spp. $>10 \mu \mathrm{m}$ were inhibited in comparison to the control treatments. Single additions of non-lytic Alexandrium supernatant increased the abundance of Chaetoceros spp. $<10 \mu \mathrm{m}$ and pennate diatoms (independent samples $t$-test, $p<0.008$ ).

When the treatments lytic and non-lytic Alexandrium were compared according to the amount of added supernatant, in low continuous additions the amount of nanoflagellates $<10 \mu \mathrm{m}$ was higher in lytic Alexandrium treatments. In high continuous additions, abundances of Chaetoceros spp., P. globosa and small and large flagellates were elevated in non-lytic Alexandrium treatments whereas dinoflagellates were more abundant in lytic Alexandrium treatments. P. globosa, Chaetoceros spp., large flagellates and pennate diatoms were suppressed in single additions of lytic Alexandrium compared to non-lytic Alexandrium (independent samples $t$-test, $p<0.05$ ).

\subsection{Bacterial abundance}

Abundance of heterotrophic bacteria ranged in between 0.6 and $0.7 \times 10^{6}$ bacteria $\mathrm{ml}^{-1}$ at the experimental start. Bacteria grew rapidly during the first $24 \mathrm{~h}$ of the experiment in all treatments (Fig. 2). Bacterial abundances in lytic Alexandrium supernatant high continuous and single additions were significantly higher than in any other treatments (multivariate test after repeated ANOVA, $p<0.05$ Tukey HSD Post Hoc). The number of bacteria declined between $48 \mathrm{~h}$ and $76 \mathrm{~h}$ in all treatments. The magnitude of this reduction differed between the three groups: lytic Alexandrium supernatant high continuous and single additions ( $29 \pm 3 \%$ loss); controls and low continuous lytic and non-lytic Alexandrium supernatant ( $45 \pm 6 \%$ loss of bacteria) and non-lytic Alexandrium high continuous and single additions ( $62 \pm 10 \%$ loss) (Tukey HSD Post Hoc test after One Way ANOVA, $p<0.05)$.

\subsection{Bacterial morphology and production}

The mean volume per bacterium was similar in all treatments after $24 \mathrm{~h}$ of incubation (One Way ANOVA, $p=0.221$, data not shown). After $96 \mathrm{~h}$, bacterial volume had decreased in the high continuous and single lytic Alexandrium supernatant treatments (from 0.056 to $0.043 \mu \mathrm{m}^{3}$ ) whereas it increased in the other treatments (from 0.056 to $0.069 \mu \mathrm{m}^{3}$ ).

Bacterial biomass after $96 \mathrm{~h}$ was significantly lower in low continuous non-lytic Alexandrium additions and high continuous lytic Alexandrium additions compared to the control (Fig. 3). Bacterial production rates reached $44 \mu \mathrm{gCl}^{-1} \mathrm{~d}^{-1}$ in the initial 


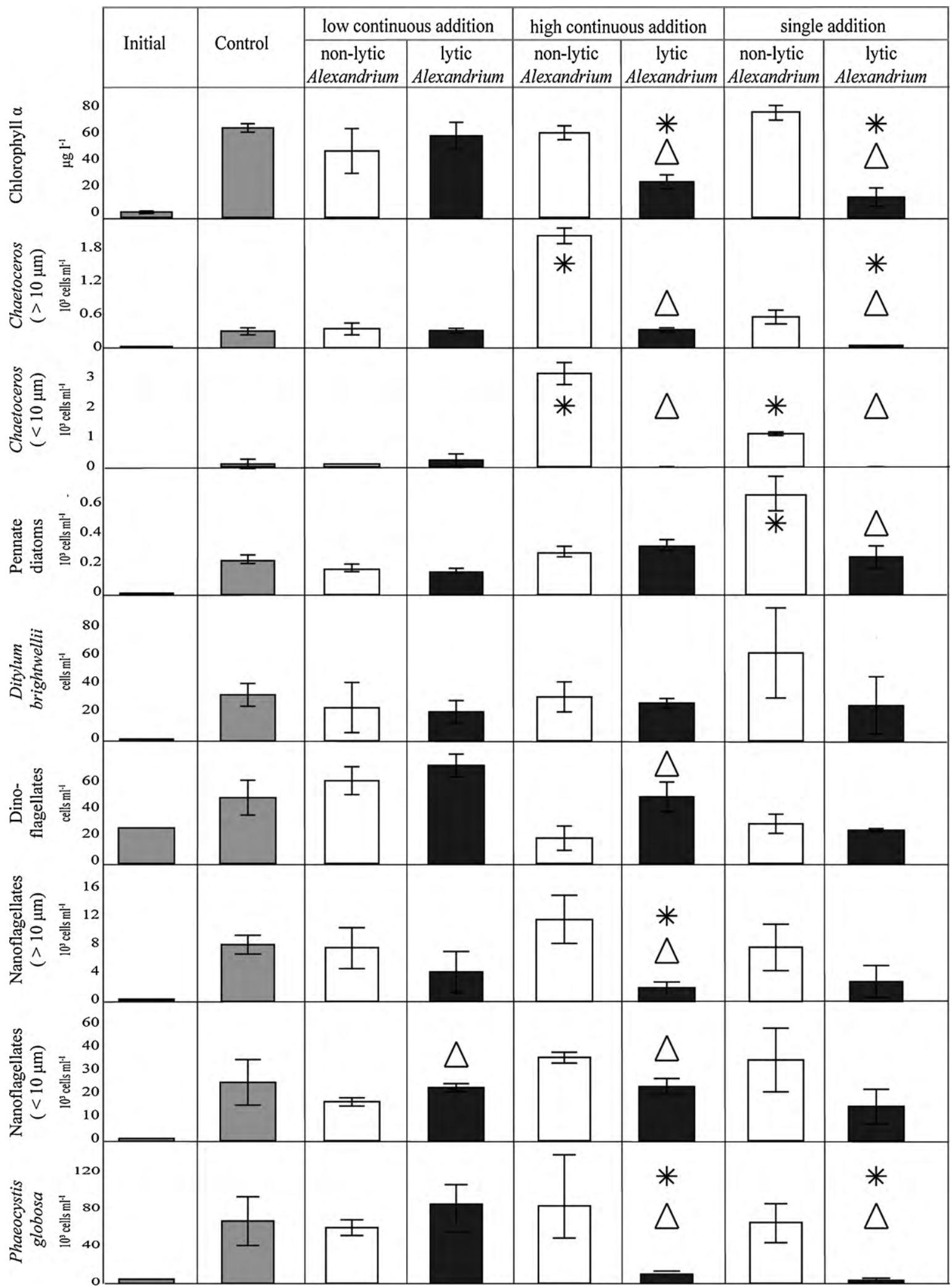

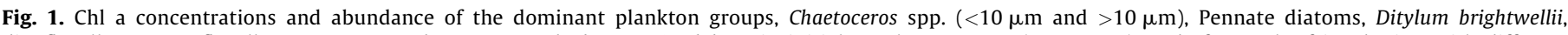

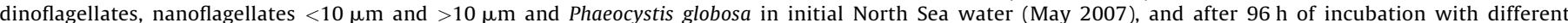

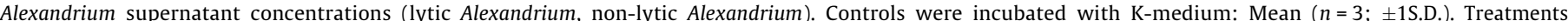

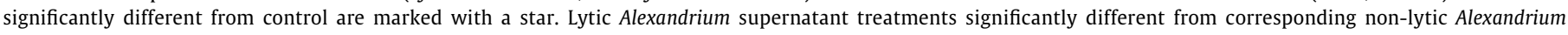
supernatant treatments are marked with a triangle. 


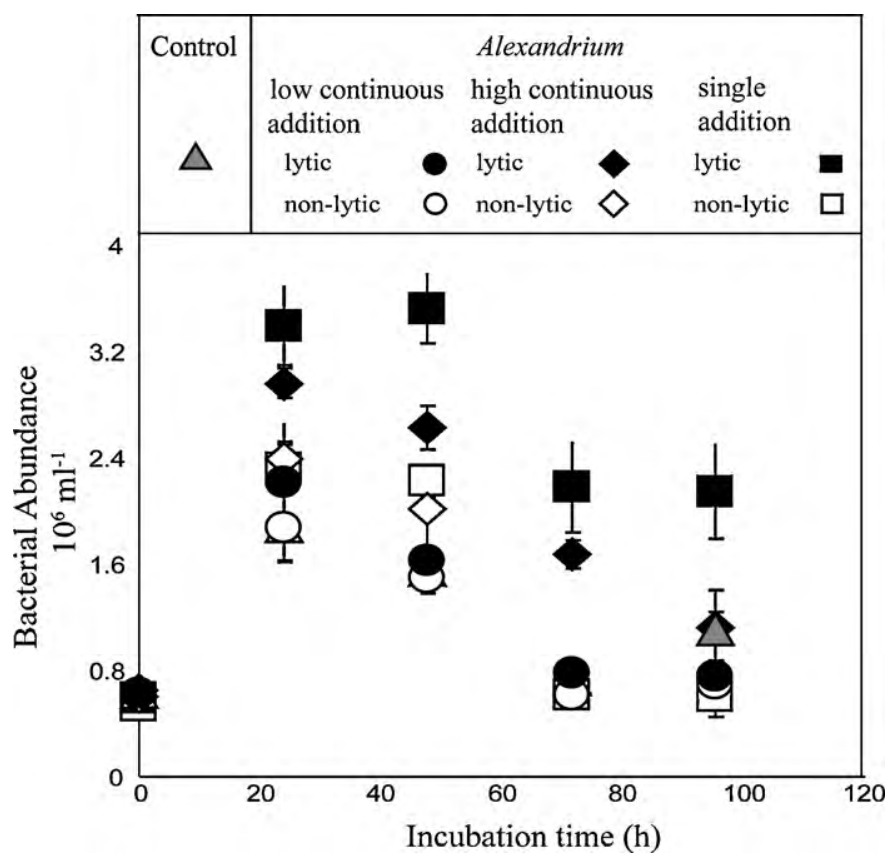

Fig. 2. Bacterial abundance in treatments containing single and continuous high and low concentrated additions of lytic and non-lytic Alexandrium supernatant during $96 \mathrm{~h}$. Controls were incubated with K-medium. Results expressed as triplicate mean \pm 1S.D.

North Sea water. Bacterial production at the end of the experiment was elevated to approximately $100 \mu \mathrm{g} \mathrm{Cl}^{-1} \mathrm{~d}^{-1}$. Bacterial production was significantly lower from the control in single non-lytic Alexandrium additions.

However, production bacteria ${ }^{-1}$ and production biomass ${ }^{-1}$ did not differ from the control with $\mathrm{K}$-medium in any of the treatments (Fig. 3).

\subsection{Bacterial community composition}

For initial North Sea water, initial lytic and non-lytic Alexandrium supernatant and control and high single lytic and non-lytic Alexandrium additions (1000 cells $\mathrm{ml}^{-1}$ ) after $96 \mathrm{~h}$, bacterial community composition was analyzed using DGGE profiles of $16 \mathrm{~S}$ rDNA fragments of duplicate samples. The genetic similarity analysis showed that the bacterial communities in initial North Sea water and in both lytic and non-lytic Alexandrium supernatant were unique and different (Fig. 4). After four days of incubation, profiles of the $16 \mathrm{~S}$ rDNA fragments recovered from bacteria from all treatments were similar, and more similar to the initial North Sea community composition than either of the $A$. tamarense supernatant. However, control and non-lytic Alexandrium treatments showed a higher similarity to each other than with lytic Alexandrium treatments (Euclidean distance similarity in UPGMA).

Comparative analysis of TRFLP fingerprints was done on the basis of one replicate from the initial North Sea water and both initial A. tamarense supernatants, and all experimental treatments $96 \mathrm{~h}$ after incubation. Two replicates were analyzed in control treatments and high lytic Alexandrium treatments. Lytic and nonlytic Alexandrium supernatants differed from each other and the initial bacterial community (Fig. 5). Bacterial community composition changed in all treatments during the experiment, but still showed high similarities among the different treatments. However, treatments with high continuous additions of lytic and non-lytic Alexandrium differed more from the control than treatments with single additions of lytic and non-lytic Alexandrium (Fig. 5).

\section{Discussion}

Our results confirmed that allelopathic substances can shape the natural plankton community without the presence of the allelopathic cells, and also impact bacteria. The lytic Alexandrium supernatant inhibited biomass of phytoplankton and large nanoflagellates but benefitted bacteria, whereas the non-lytic Alexandrium supernatant provoked higher final abundances in several plankton species and benefitted nanoflagellates and bacteria.

Allelopathy is the impact of secondary metabolites, produced by phytoplankton, on growth and functions of other microbes (Cembella, 2003; Legrand et al., 2003; Gross, 2003; Graneli and Hansen, 2006; Ianora et al., 2006). According to this definition, both $A$. tamarense strains, lytic and non-lytic Alexandrium, exhibited allelopathy. However, adding a supernatant of any algal culture probably will show some "effects" on a community when compared to adding medium. Some of these observations may result from feedback mechanisms within the microbial community (i.e. an increase in bacterial biomass can explain an increase in heterotrophic nanoflagellate biomass). The beneficial effects of the non-lytic Alexandrium supernatant on Chaetoceros spp. may be explained by metal complexing properties of extracellular organic material, derived from phytoplankton, which can affect trace metal availability as well as seawater toxicity (Croot et al., 2000; Vasconcelos et al., 2002; Rijkenberg et al., 2008). In a laboratory study, growth of the diatom Phaeodactylum tricornutum was enhanced by algal exudates of different macro- and microalgae. The exudates supported nutrient uptake but also changed the intensity of production and nature of $P$. tricornutum own exudates (Vasconcelos and Leal, 2008).

Previous comparisons of both Alexandrium strains showed that only the lytic strain (Alex2) affected a whole range of different target species whereas the non-lytic strain (Alex 5) showed no negative effect (Tillmann and Hansen, 2009; Tillmann et al., 2009). Therefore, we interpret all changes caused by the lytic Alexandrium that differ from changes caused by the non-lytic strain in this study as due to lytic compounds.

High lytic Alexandrium supernatant additions inhibited the growth of $P$. globosa, whereas diatom abundance was not significantly negatively affected in comparison to the control (except Chaetoceros $>10 \mu \mathrm{m}$ in the single addition). However, compared to non-lytic supernatant, lytic Alexandrium supernatant had a significantly negative effect on diatoms. In previous field experiments, several diatom species were only slightly inhibited by $A$. tamarense allelochemicals (Fistarol et al., 2004). When compared to other target species, Thalassiosira weissflogii was relatively resistant to lytic substances released from different Alexandrium species (Tillmann et al., 2008) supporting the hypothesis that diatoms are more resistant to the allelochemical substances produced by toxic dinoflagellates than ciliates and flagellates. However, recent co-incubation experiments of $A$. tamarense and 10 different phytoplankton species showed that both diatom species (Skeletonema costatum, T. weissflogii) clearly were affected, with $S$. costatum being amongst the most sensitive species (Tillmann and Hansen, 2009). Species-specific consequences of allelopathy are known from other allelopathic dinoflagellates such as Karlodinium micrum and Karenia brevis (Adolf et al., 2006; Kubanek et al., 2005). When exudates of the redtide dinoflagellate $K$. brevis were tested on 12 different phytoplankton target species, only six of them were inhibited compared to the control (Kubanek et al., 2005). Among the diatoms tested by these authors, $S$. costatum and T. weissflogii, were also among the most sensitive target species.

During the first $24 \mathrm{~h}$, bacteria grew in all treatments due to the labile carbon added in form of peptone. Since $\mathrm{PO}_{4}$ and $\mathrm{NO}_{3}$ were 


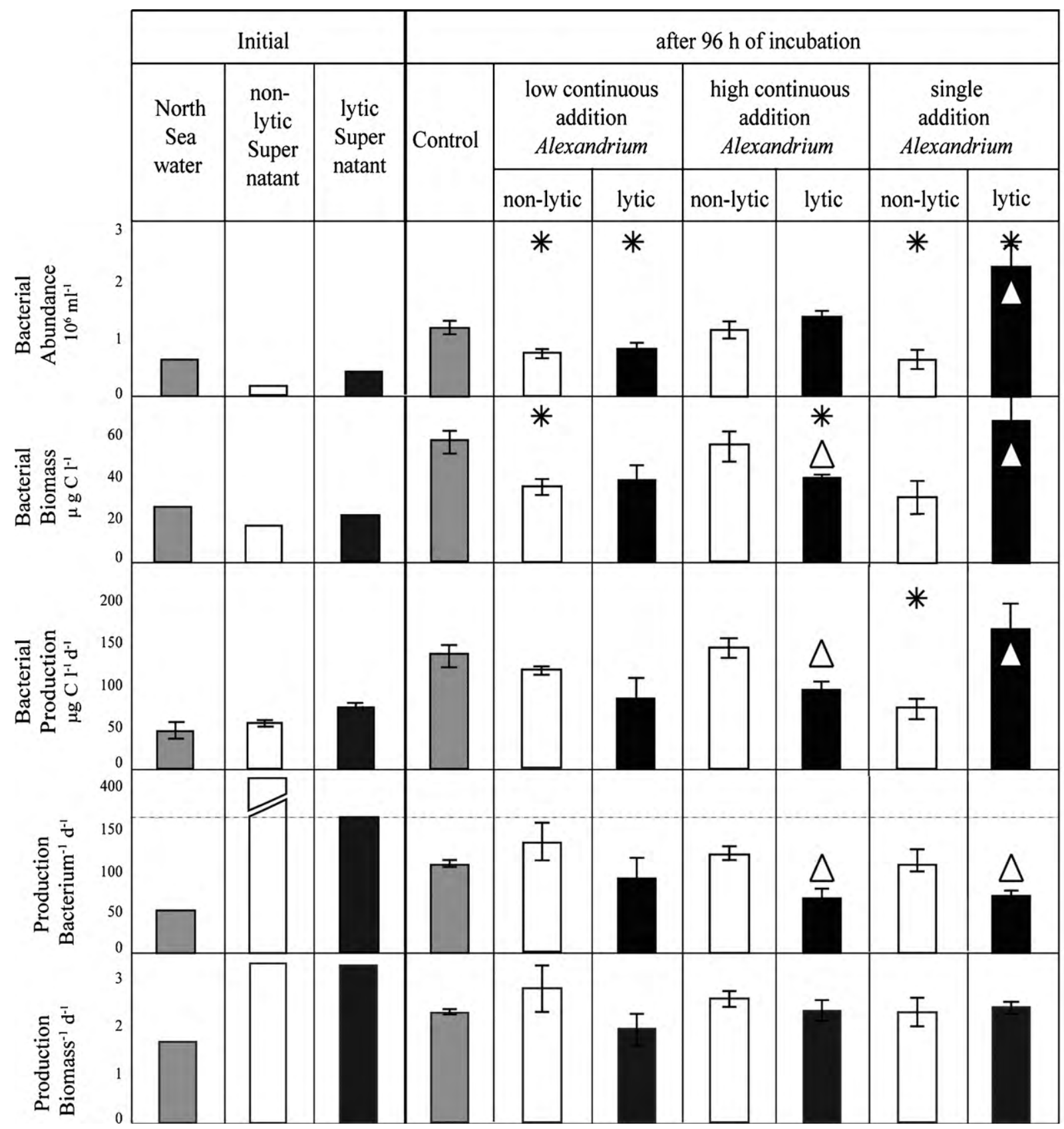

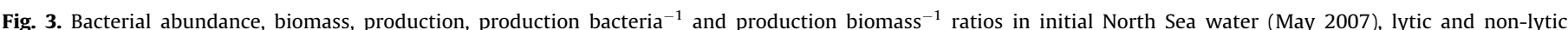

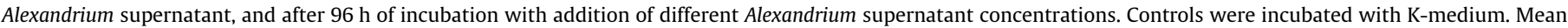

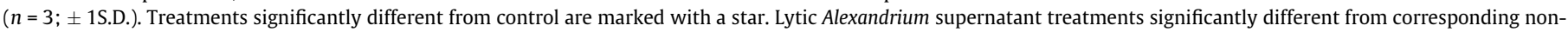
lytic Alexandrium supernatant treatments are marked with a triangle.

added in excess, bacteria were probably carbon limited when bacterial abundance stabilized after $24 \mathrm{~h}$. Bacteria reached higher growth rates and bacterial yields in treatments containing high additions of supernatant. Highest bacterial yields were reached in lytic Alexandrium single additions. The release of DOM is usually an important source of labile dissolved organic carbon (DOC) for bacteria (Valiela, 1995). Dense algal cultures contain DOM due to phytoplankton exudates. The addition of supernatant provided an additional source for DOC, and therefore supported higher bacterial yields in both lytic and non-lytic Alexandrium supernatant treatments, compared to control treatments. However, DOM deriving from $A$. tamarense cultures was found to be essentially bacteria resistant (Chen and Wangersky, 1996). Additionally, lysis of plankton in lytic Alexandrium supernatant treatments may have increased the DOM pool even further. Mixed culture trials of $R$. salina and the allelopathic haptophyte $P$. parvum lead to a significant increase of DOC concentration after $30 \mathrm{~min}$ and an increase in bacterial biomass after 6-12 h (Uronen et al., 2007). We assume that DOC released from lysing cells was available to bacteria in lytic Alexandrium supernatant treatments.

Bacterial growth usually results in a slightly delayed growth of bacterivores; those have to adapt to the new nutrient conditions, but can reach high growth rates (4-6 h doubling time) (Weisse and Scheffelmoser, 1991; Jurgens et al., 2000). When bacterial grazers become abundant, bacteria decrease rapidly. We could observe this rapid decrease in all treatments after $48 \mathrm{~h}$ of incubation. However, bacterial decrease (a proxy for bacterivory) was lower in single and high continuous additions of lytic Alexandrium 


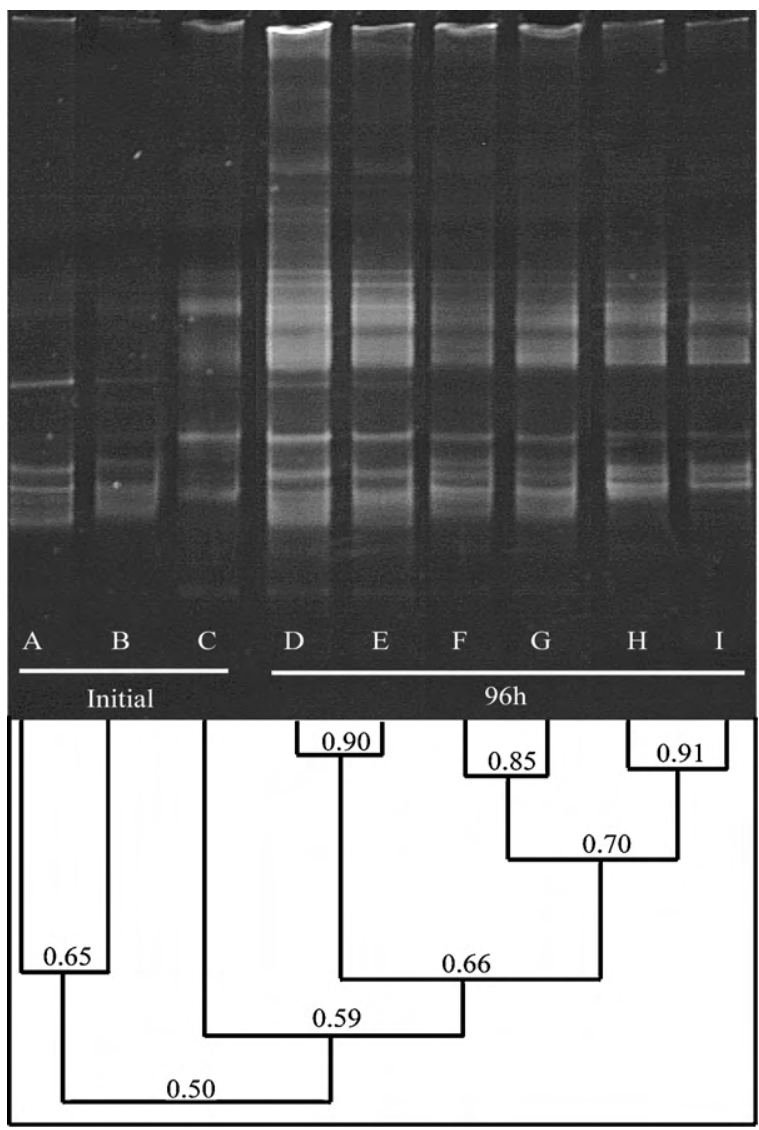

Fig. 4. DGGE profiles of $16 \mathrm{~S}$ rRNA gene fragments from (A) lytic Alexandrium culture, (B) non-lytic Alexandrium culture, (C) initial North Seawater, and treatments (two replicates each) with high single additions of: (D, E) lytic Alexandrium supernatant; (F, G) non-lytic Alexandrium supernatant. (H, I) K-medium control after $96 \mathrm{~h}$ of incubation. Cluster analysis (UPGMA) showing the similarity of the lanes is shown below the gel image. Values give Euclidean distance similarity between the lanes.

supernatant (30\%) compared to non-lytic additions (60\%), suggesting that predation pressure was lower in treatments containing lytic compounds.

Nanoflagellate grazing accounts for most of the protistan bacterivory in plankton (Jürgens and Massana, 2008). Previous studies have shown that the presence of allelopathic substances could eliminate up to $80 \%$ of nanoflagellates over 3-4 days, and therefore contribute to a high bacterial abundance in algal filtrate treatments (Fistarol et al., 2003, 2004). Our study confirms these results, since the abundance of flagellates after $96 \mathrm{~h}$ of incubation was suppressed in lytic Alexandrium compared to non-lytic Alexandrium treatments.

A strong top down control in nutrient rich conditions may lead to a high production per bacterium but a low bacterial abundance (Ducklow et al., 2001). The larger size of bacteria and the relatively higher production per bacterium in non-lytic Alexandrium treatments could be explained by better growth caused by nutrient recirculation, a side effect of nanoflagellate grazing due to sloppy feeding. However, production biomass ${ }^{-1}$ did not differ between lytic Alexandrium and all other treatments, indicating that bacterial production after continuous and single addition was not affected by $A$. tamarense supernatant after $96 \mathrm{~h}$.

The effect of allelochemicals on bacterial abundance and production has been reported in a few studies (Nielsen et al., 1990; Fistarol et al., 2004; Uronen et al., 2007). In this study, the effect of allelochemicals on bacterial composition in natural communities is reported for the first time. Studies on Alexandrium spp. blooms revealed a high abundance of bacteria that were repeatedly found in association to phytoplankton blooms (Wichels et al., 2004). Bacteria associated with diatom cultures revealed specific bacterial "satellite" communities (Schäfer et al., 2002; Grossart et al., 2005; Kaczmarska et al., 2005). In Alexandrium cultures, the presence of specific bacterial consortia may be explained by symbiotic relationships between bacteria and the dinoflagellate (Amaro et al., 2005; Jasti et al., 2005). Additionally, cell wall components, exudates, pigment composition and life cycle features of the algae may also select for specific bacterial consortia. However, bacterial communities associated to algae are not necessarily species specific, and strains of the same algae can harbour different bacterial communities (Sapp et al., 2007).

In this study, the initial composition of each bacterial "satellite" community was very different among the two Alexandrium supernatants and the North Sea water. After $96 \mathrm{~h}$ of incubation, the bacterial community shared a high similarity in all treatments and was closer to the initial North Seawater than to any Alexandrium supernatant. The development of the bacterial community towards a similar composition among the treatments may be due to the addition of nutrients, especially peptone, and the selection for copiotroph bacteria (Lauro et al., 2009). If bacterial "satellite" communities can be explained by their adaptation to

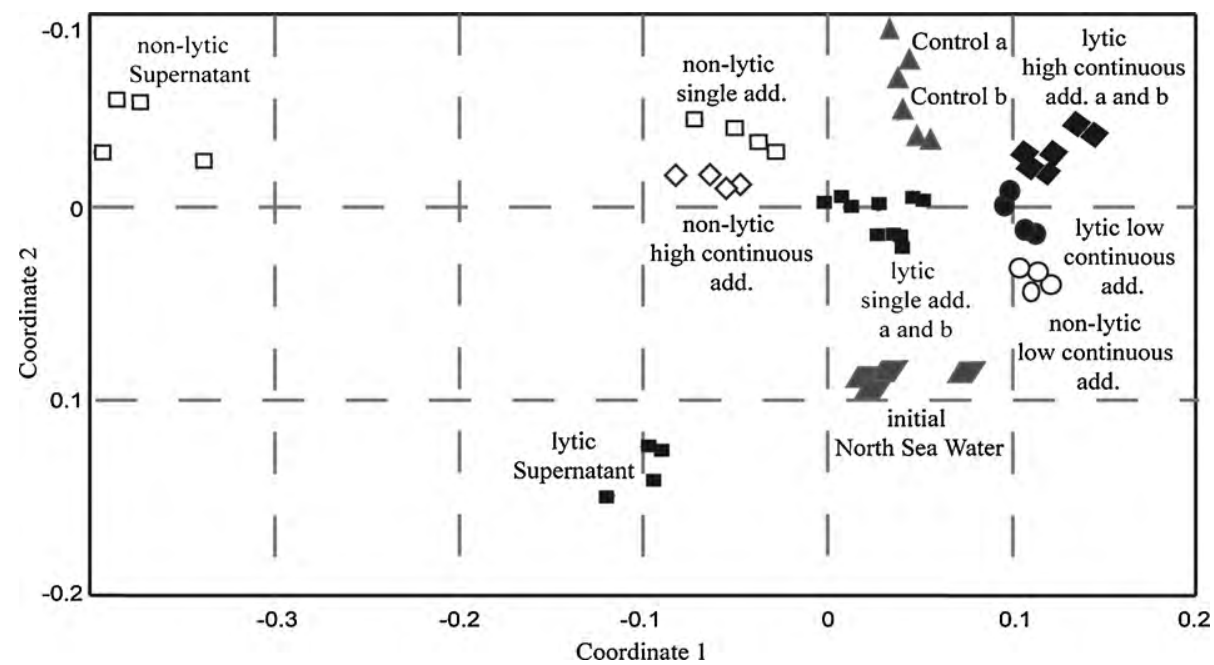

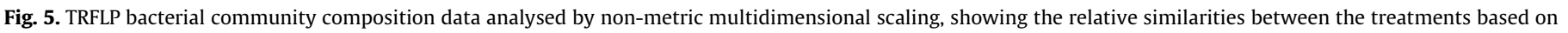
Euclidean distribution.

Please cite this article in press as: Weissbach, A., et al., Allelopathic potential of the dinoflagellate Alexandrium tamarense on marine microbial communities. Harmful Algae (2010), doi:10.1016/j.hal.2010.05.007 
algal released DOM (Sapp et al., 2007), an easily converted carbon source such as peptone may have made it irrelevant for bacteria to take up algal released DOM, and therefore, no strong bacterial selection could be observed.

In nature, allelochemicals are assumed to be continuously released into the surrounding seawater but not much is known about degradation of the compound or adaptation of target organisms. Allelochemicals of $A$. tamarense have been shown to be quite stable at room temperature and not degraded by the bacteria consortium present in the culture (Ma et al., 2009). Our results showed that addition of one high pulse of lytic A. tamarense supernatant affected the natural plankton community more than adding almost the same quantity of supernatant semi-continuously. Experimental observations of cell blistering and lysis in target species indicate that the compounds primarily seem to act upon the outer membrane of the target organisms (Tillmann et al., 2007). This binding probably leads to a removal of compounds from solution, as lysis of target species is not only depending on the concentration of donor cells but, interestingly, also depends on concentration of the cells of the targeted species (Tillmann, 2003; Tillmann et al., 2007). In addition, initial characterizations have shown a general "stickiness" of the compounds to all kind of surfaces, e.g. for filter material and for plastic containers compared to glass (Ma et al., 2009). Consequently, lytic substances binding to different matrices like growing $P$. globosa colonies, diatoms and organic surfaces may explain the lower efficiency of the continuous additions. Hence, as the amount of matrices increased over time, the impact of lytic substances did not accumulate but weakened in the microcosms. Furthermore, the phytoplankton community in treatments with continuous additions of $A$. tamarense supernatant might have adapted to the exposure of allelochemicals or might have metabolized or degraded allelopathic compounds.

Recently, allelopathy has been questioned as to its involvement in algal bloom formation (Jonsson et al., 2009). A meta-analysis of data from several experiments regarding allelopathy showed that donor organisms provoked inhibitory effects towards other species only at Chl a concentrations $>5 \mu \mathrm{g} \mathrm{l}^{-1}$ (bloom conditions). On the other hand, studies with low concentrations of donor organisms are scarce. In our study, the lower tested concentrations of lytic Alexandrium supernatant did not obviously impact the natural plankton community. However, motile phytoplankter, such as $A$. tamarense, reach highest densities in calm weather conditions and accumulate in horizontal layers, along thermoclines or the water surface (MacIntyre et al., 1997; Mouritsen and Richardson, 2003; Ryan et al., 2008). High concentrations of cells, and thus, secondary metabolites, similar to those in this experiment, can accompany $A$. tamarense cells and impact the phytoplankton community around these layers. There is increasing interest in exploring microbial interactions at the nanometer to millimeter scale (Azam and Malfatti, 2007). Microorganisms possess complex and sophisticated sensory and behavioral adaptations to their environment (Jennings, 1906). Diverse populations of marine microbes have been shown to markedly modify their foraging behavior when navigating a patchy habitat (Seymour et al., 2009) and may avoid allelopathic compounds via negative chemotaxis. Our results indicate that allelochemicals have no direct negative impact on bacteria. Layers of lytic dinoflagellates could therefore be bacterivore free, nutrient rich microhabitats for bacteria. However, the interplay between allelopathy and bacterivory needs to be further investigated.

\section{Acknowledgements}

We thank the crew of the R/V Uthörn for sampling. Funding was provided by the Faculty of Natural Sciences and Technology, University of Kalmar ( $\mathrm{CL}$ and $\mathrm{AW}$ ), the European Commission under the FP7 (PEOPLE-IEF220732-ALGBACT to CL), The Alfred Wegener Institute for Polar and Marine Research (AWI) (CL and UT), and The Max Planck Institute for Marine Microbiology in Bremen, Germany (AW).[TS]

\section{References}

Adolf, J.E., Bachvaroff, T.R., Krupatkina, D.N., Nonogaki, H., Brown, P.J.P., Lewitus, A.J., Harvey, H.R., Place, A.R., 2006. Species specificity and potential roles of Karlodinium micrum toxin. African Journal of Marine Science 28, 415-419.

Alpermann, T.J., Beszteri, B., John, U., Tillmann, U., Cembella, A.D., 2009. Implications of life-history transitions on the population genetic structure of the toxigenic marine dinoflagellate Alexandrium tamarense. Molecular Ecology 18 (10), 21222133.

Amaro, A.M., Fuentes, M.S., Ogalde, S.R., Venegas, J.A., Suarez-Isla, B.A., 2005. Identification and characterization of potentially algal-lytic marine bacteria strongly associated with the toxic dinoflagellate Alexandrium catenella. Journal of Eukaryotic Microbiology 52 (3), 191-200.

Anderson, D.M., 1997. Bloom dynamics of toxic Alexandrium species in the northeastern US. Limnology and Oceanography 42 (5), 1009-1022.

Azam, F., Malfatti, F., 2007. Microbial structuring of marine ecosystems. Nature Reviews Microbiology 5, 782-791.

Boström, K.H., Simu, K., Hagstrom, A., Riemann, L., 2004. Optimization of DNA extraction for quantitative marine bacterioplankton community analysis. Limnology and Oceanography-Methods 2, 365-373.

Cembella, A.D., 2003. Chemical ecology of eukaryotic microalgae in marine ecosystems. Phycologia 42 (4), 420-447.

Chen, W.H., Wangersky, P.J., 1996. Rates of microbial degradation of dissolved organic carbon from phytoplankton cultures. Journal of Plankton Research 18 (9), 1521-1533.

Croot, P.L., Moffett, J.W., Brand, L.E., 2000. Production of extracellular Cu complexing ligands by eucaryotic phytoplankton in response to $\mathrm{Cu}$ stress. Limnology and Oceanography 45 (3), 619-627.

Doucette, G., 1995. Interactions between bacteria and harmful algae: a review. Natural Toxins 3, 65-74.

Ducklow, H., Carlson, C., Church, M., Kirchman, D., Smith, D., Steward, G., 2001. The seasonal development of the bacterioplankton bloom in the Ross Sea, Antarctica 1994-1997. Deep-Sea Research Part I-Topical Studies in Oceanography 48, 4199-4221.

Fistarol, G.O., Legrand, C., Graneli, E., 2003. Allelopathic effect of Prymnesium parvum on a natural plankton community. Marine Ecology-Progress Series $255,115-125$.

Fistarol, G.O., Legrand, C., Selander, E., Hummert, C., Stolte, W., Graneli, E., 2004. Allelopathy in Alexandrium spp.: effect on a natural plankton community and on algal monocultures. Aquatic Microbial Ecology 35 (1), 45-56.

Gasol, J.M., Del Giorgio, P.A., 2000. Using flow cytometry for counting natural planktonic bacteria and understanding the structure of planktonic bacterial communities. Scientia Marina 64 (2), 197-224.

Graneli, E., Hansen, P.J., 2006. Allelopathy in Harmful Algae: a mechanism to compete for resources? In: Graneli, E., Turner, J. (Eds.), Ecology of Harmful Algae, Series: Ecological Studies, vol. 189. pp. 189-201.

Green, D.H., Llewellyn, L.E., Negri, A.P., Blackburn, S.I., Bolch, C.J.S., 2004. Phylogenetic and functional diversity of the cultivable bacterial community associated with the paralytic shellfish poisoning dinoflagellate Gymnodinium catenatum. FEMS Microbiology Ecology 47 (3), 345-357.

Gross, E.M., 2003. Allelopathy of aquatic autotrophs. Critical Reviews in Plant Sciences 22 (3-4), 313-339.

Grossart, H.P., Levold, F., Allgaier, M., Simon, M., Brinkhoff, T., 2005. Marine diatom species harbour distinct bacterial communities. Environmental Microbiology 7 (6), 860-873.

Haas, L.W., 1982. Improved epifluorescence microscopy for observing planktonic microorganisms. Annales De L Institut Oceanographique 58, 261-266.

Hammer, O., Harper, D.A.T., Ryan, P.D., 2001. PAST: Palaeontological Statistics software package for education and data analysis. Palaeontologia Electronica 4 (1), 9.

Hay, M.E., Kubanek, J., 2002. Community and ecosystem level consequences of chemical cues in the plankton. Journal of Chemical Ecology 28 (10), 20012016.

Ianora, A., Boersma, M., Casotti, R., Fontana, A., Harder, J., Hoffmann, F., Pavia, H. Potin, P., Poulet, S.A., Toth, G., 2006. New trends in marine chemical ecology. Estuaries and Coasts 29 (4), 531-551.

Jasti, S., Sieracki, M.E., Poulton, N.J., Giewat, M.W., Rooney-Varga, J.N., 2005. Phylogenetic diversity and specificity of bacteria closely associated with Alexandrium spp. and other phytoplankton. Applied and Environmental Microbiology 71 (7), 3483-3494.

Jennings, H.S., 1906. The Behaviour of the Lower Organisms. Columbia university press, New York.

Jespersen, A.M., Christoffersen, K., 1987. Measurements of Chlorophyll-a from phytoplankton using ethanol as extraction solvent. Archiv für Hydrobiologie 109 (3), 445-454.

Jonsson, P.R., Pavia, H., Toth, G., 2009. Formation of harmful algal blooms cannot be explained by allelopathic interactions. Proceedings of the National Academy of Sciences of the United States of America 106 (27), 11177-11182. 
Jurgens, K., Gasol, J.M., Vaque, D., 2000. Bacteria-flagellate coupling in microcosm experiments in the Central Atlantic Ocean. Journal of Experimental Marine Biology and Ecology 245, 127-147.

Jürgens, K., Massana, R., 2008. Protistan grazing on marine bacterioplankton. In: Kirchmann, D.L. (Ed.), Microbial Ecology of the Oceans. John Wiiley and Sons Inc., New Jersey.

Kaczmarska, I., Ehrman, J.M., Bates, S.S., Green, D.H., Leger, C., Harris, J., 2005. Diversity and distribution of epibiotic bacteria on Pseudo-nitzschia multiseries (Bacillariophyceae) in culture, and comparison with those on diatoms in native seawater. Harmful Algae 4 (4), 725-741.

Keller, M.D., Selvin, R.C., Claus, W., Guillard, R.R.L., 1987. Media for the Culture of Oceanic Ultraphytoplankton. Journal of Phycology 23, 633-638.

Kroer, N., 1994. Relationships between biovolume and carbon and nitrogen-content of bacterioplankton. FEMS Microbiology Ecology 13 (3), 217-223.

Kubanek, J., Hicks, M.K., Naar, J., Villareal, T., 2005. Does the red tide dinoflagellate Karenia brevis use allelopathy to out-compete other phytoplankton? Limnology and Oceanography 50, 883-895.

Lauro, F.M., McDougald, D., Thomas, T., Williams, T.J., Egan, S., Rice, S., DeMaere, M.Z., Ting, L., Ertan, H., Johnson, J., et al., 2009. The genomic basis of trophic strategy in marine bacteria. Proceedings of the National Academy of Sciences of the United States of America 106 (37), 15527-15533.

Legrand, C., Rengefors, K., Fistarol, G.O., Graneli, E., 2003. Allelopathy in phytoplankton-biochemical, ecological and evolutionary aspects. Phycologia 42 (4), 406-419.

Ma, H.J., Krock, B., Tillmann, U., Cembella, A., 2009. Preliminary characterization of extracellular allelochemicals of the toxic marine dinoflagellate Alexandrium tamarense using a Rhodomonas salina bioassay. Marine Drugs 7, 497-522.

MacIntyre, J.G., Cullen, J.J., Cembella, A.D., 1997. Vertical migration, nutrition and toxicity in the dinoflagellate Alexandrium tamarense. Marine Ecology-Progress Series 148 (1-3), 201-216.

Mayali, X., Azam, F., 2004. Algicidal bacteria in the sea and their impact on algal blooms. Journal of Eukaryotic Microbiology 51 (2), 139-144.

Mouritsen, L.T., Richardson, K., 2003. Vertical microscale patchiness in nano- and microplankton distributions in a stratified estuary. Journal of Plankton Research 25 (7), 783-797.

Muyzer, G., Smalla, K., 1998. Application of denaturing gradient gel electrophoresis (DGGE) and temperature gradient gel electrophoresis (TGGE) in microbial ecology. Antonie Van Leeuwenhoek International Journal of General and Molecular Microbiology 73, 127-141.

Nielsen, T.G., Kiorboe, T., Bjornsen, P.K., 1990. Effects of a Chrysochromulina-Polylepis Subsurface Bloom on the Planktonic Community. Marine Ecology-Progress Series 62, 21-35.

Ribalet, F., Intertaglia, L., Lebaron, P., Casotti, R., 2008. Differential effect of three polyunsaturated aldehydes on marine bacterial isolates. Aquatic Toxicology 86 (2), 249-255.

Riemann, L., Steward, G.F., Azam, F., 2000. Dynamics of bacterial community composition and activity during a mesocosm diatom bloom. Applied and Environmental Microbiology 66 (2), 578-587.

Rijkenberg, M.J.A., Gerringa, L.J.A., Timmermans, K.R., Fischer, A.C., Kroon, K.J., Buma, A.G.J., Wolterbeek, B.T., de Baar, H.J.W., 2008. Enhancement of the reactive iron pool by marine diatoms. Marine Chemistry 109 (1-2), 29-44.

Ryan, J.P., Gower, J.F.R., King, S.A., Bissett, W.P., Fischer, A.M., Kudela, R.M., Kolber, Z., Mazzillo, F., Rienecker, E.V., Chavez, F.P., 2008. A coastal ocean extreme bloom incubator. Geophysical Research Letters 35 (12).
Sala, M.M., Balague, V., Pedros-Alio, C., Massana, R., Felipe, J., Arin, L., Illoul, H. Estrada, M., 2005. Phylogenetic and functional diversity of bacterioplankton during Alexandrium spp. blooms. FEMS Microbiology Ecology 54 (2), 257-267.

Sapp, M., Schwaderer, A.S., Wiltshire, K.H., Hoppe, H.G., Gerdts, G., Wichels, A., 2007. Species-specific bacterial communities in the phycosphere of microalgae? Microbial Ecology 53 (4), 683-699.

Schäfer, H., Abbas, B., Witte, H., Muyzer, G., 2002. Genetic diversity of 'satellite' bacteria present in cultures of marine diatoms. FEMS Microbiology Ecology 42 (1), 25-35.

Seymour, J.R., Marcos, Stocker, R., 2009. Resource patch formation and exploitation throughout the marine microbial food web. American Naturalist 173 (1), E15E29.

Simon, M., Azam, F., 1989. Protein-content and protein-synthesis rates of planktonic marine-bacteria. Marine Ecology-Progress Series 51 (3), 201-213.

Smayda, T.J., 1997. Harmful algal blooms: their ecophysiology and general relevance to phytoplankton blooms in the sea. Limnology and Oceanography 42 (5), 1137-1153.

Smith, D., Azam, F., 1992. A simple, economical method for measuring bacterial protein synthesis rates in seawater using ${ }^{3} \mathrm{H}$-leucine. Marine Microbial Food Webs 6, 107-114.

Tillmann, U., 2003. Kill and eat your predator: a winning strategy of the planktonic flagellate Prymnesium parvum. Aquatic Microbial Ecology 32, 73-84.

Tillmann, U., Alpermann, T.L., da Purificacao, R.C., Krock, B., Cembella, A., 2009. Intra-population clonal variability in allelochemical potency of the toxigenic dinoflagellate Alexandrium tamarense. Harmful Algae 8 (5), 759-769.

Tillmann, U., Hansen, P., 2009. Allelopathic effects of Alexandrium tamarense on other algae: evidence from mixed growth experiments. Aquatic Microbial Ecology 57, 101-112.

Tillmann, U., John, U., 2002. Toxic effects of Alexandrium spp. on heterotrophic dinoflagellates: an allelochemical defence mechanism independent of PSPtoxin content. Marine Ecology-Progress Series 230, 47-58.

Tillmann, U., John, U., Cembella, A., 2007. On the allelochemical potency of the marine dinoflagellate Alexandrium ostenfeldii against heterotrophic and autotrophic protists. Journal of Plankton Research 29 (6), 527-543.

Tillmann, U., John, U., Krock, B., Cembella, A., 2008. Allelopathic effects of bioactive compounds produced by harmful algae. In: Moestrup, O., et al. (Eds.), Proceedings of the 12th International Conference on Harmful Algae. ISSHA and IOCUNESCO, Copenhagen, Denmark, pp. 12-18.

Uronen, P., Kuuppo, P., Legrand, C., Tamminen, T., 2007. Allelopathic effects of Toxic Haptophyte Prymnesium parvum lead to release of dissolved organic carbon and increase in bacterial biomass. Microbial Ecology 54 (1), 183-193.

Valiela, I., 1995. Marine Ecological Processes. Springer Verlag, New York Inc.

Vasconcelos, M., Leal, M.F.C., 2008. Exudates of different marine algae promote growth and mediate trace metal binding in Phaeodactylum tricornutum. Marine Environmental Research 66 (5), 499-507.

Vasconcelos, M., Leal, M.F.C., van den Berg, C.M.G., 2002. Influence of the nature of the exudates released by different marine algae on the growth, trace metal uptake, and exudation of Emiliania huxleyi in natural seawater. Marine Chemistry $77(2-3), 187-210$.

Weisse, T., Scheffelmoser, U., 1991. Uncoupling the Microbial Loop - Growth and Grazing Loss Rates of Bacteria and Heterotrophic Nanoflagellates in the NorthAtlantic. Marine Ecology-Progress Series 71, 195-205.

Wichels, A., Hummert, C., Elbrächter, M., Luckas, B., Schutt, C., Gerdts, G., 2004 Bacterial diversity in toxic Alexandrium tamarense blooms off the Orkney Isles and the Firth of Forth. Helgoland Marine Research 58 (2), 93-103. 